\title{
The Impact of International Crises on the Refugees Personal Status
}

\author{
Dr. Bassam Nahar Albton \\ Judge in Elementary Legal Court in Amman \\ Dr. Nusaiba Ali Almousa \\ Assistance Professor, Amman arab university
}

DOI: $10.7176 / \mathrm{JEP} / 11-30-01$

Publication date:October $31^{\text {st }} 2020$

\section{Introduction:}

Shariah is provided by Allah in the aim of repopulating the earth and establishing the Islamic caliphate. It aims to meet the interests of people and preventing any damage to people's interests. All the provisions of the judicial legislations aim at meeting the aforementioned goals of Shariah.

The Hashemite Kingdom of Jordan went through several internal and external events recently. Such events shall affect the way of implementing the applicable laws, codes and regulations by courts in general and Shariah courts in particular. For example, they shall affect the way of implementing (the Law of Procedure before Shariah Courts). They shall affected the way of implementing the applicable laws, codes and regulations that regulate the personal status of people in general and refugees in particular in Jordan. In other words, Jordan is affected by the events experienced by Muslims in neighbouring countries. It should be noted that the Jordanian Law of Procedure before Shariah Courts include the litigation procedures in cases involving personal status of Muslims regardless of their nationalities.

In the light of the aforementioned information, the present study aimed to explore the impact of international crises on the refugees' personal status. It aimed to explore the significant impacts of crises on the implementation of the Law of Procedure before Shariah Courts. The latter law is an applicable law. It is implemented by Shariah Courts in Jordan. The present study aimed to analyse the latter impacts through carrying out a practical analytical investigations. The present study is significant because it aimed to shed a light on the most significant events and the way it affected the way of implementing the Law of Procedure before Shariah Courts.

\section{Statement of the Problem}

The present study is significant. That is because it aimed to shed a light on the impacts of the latest events that are derived from international crises on the implementation of the Law of Procedure before Shariah Courts. This study aimed to shed a light on the impacts of such events on the implementation of other laws, codes and regulations that are applicable in Shariah courts in Jordan. Such latest events include: wars, forced migration and international treaties. The present study aimed to identify the significant role of religious institutions in the light of experiencing several international events (e.g. violent events, wars and treaties) in the neighbouring countries

The present study aimed to answer the following questions:

Q.1. Did the wars and conflicts in the neighbouring countries affected the implementations of the Jordanian Law of Procedure before Shariah Courts?

Q.2. What is the severity of the impacts of international treaties on the implementations of the Jordanian Law of Procedure before Shariah Courts?

Q.3. To which degree are the amendments ofthe Jordanian Law of Procedure before Shariah Courts fit with the surrounding events?

\section{The Study's Methodology:}

The researchers adopted an inductive approach. They collected data from the most significant books on the four schools of Shairah. They collected data from the books of interoperation, the books on the verses of Quran that include provisions. They collected data from the books on Hadith, the books on biography, and positive laws.

The researchers of the present study adopted a descriptive analytical approach. Through adopting this approach, they analysed the relevant legislations and opinions of jurists

\section{Structure of the Research}

The researchers of the present study aimed to explore the impact of international crises on the refugees' personal status. They structure of the present study is presented below:

Part one: The meaning of the term (international crises) and the impacts of such crises on the implementations of 
laws by personal status courts (Shariah courts)

Section one: The meaning of the term (international crises) and the impacts of such crises on the implementations of the Jordanian Law of Procedure before Shariah Courts.

Section two: The impacts of international crises on making decisions under discretion by the Jordanian Shariah courts.

Part two: The impacts of international crises and the Universal Declaration of Human Rights on the rights of refugees and missing people

Section one: The impacts of international crises on enforcing the provisions related to the rights of missing people Section two: The Universal Declaration of Human Rights

Part one: The meaning of the term (international crises) and the impacts of such crises on the implementations of laws by personal status courts (Shariah courts)

Section one: The meaning of the term (international crises) and the impacts of such crises on the implementations of the Jordanian Law of Procedure before Shariah Courts.

Crises: This term refers to the time of intense difficulty ${ }^{12}$. Crisis may refer to a state of a transition or a state of instability. It leads to a dramatic change. This change may be positive or bad. A crisis may refer to the peak in a state of tension in national, regional or international relations. At this state, one of the involved parties may probably initiate a war against the other party/parties ${ }^{3}$.

Crisis may be defined as a set of conflicts between two countries or more. It may lead to initiating a war. During the crisis, the decision makers have to take a stand on situation that threatens the interests of their governments. They have to take strategic decisions in response to such threatening situation ${ }^{4}$.

The Middle East region has been going through several international and regional crises. Such crises include: the Arab-Israeli conflict since 1948, the war of 1967, and First Palestinian Intifada of 1989. After that, the Iraqi crisis occurred. It has several negative impacts on all the countries of the Middle East in general and Jordan in particular. After that, the Arab Spring. In addition, the Syrian Crisis occurred in 2011. It led to the immigration of millions of people searching for security and running from war.

According to the United Nations High Commissioner for Refugees, there are about 68,500,000 immigrants who were forced to immigrate worldwide ${ }^{5}$. Such forced immigration is attributed to regional and international wars and conflicts. By the end of June, 12 million Syrian immigrants and 4 million Iraqi immigrants immigrated due to the Syrian and Iraqi wars. The latter wars serve as major turning points in the history of the Middle East ${ }^{6}$.

As for the Syrian crisis, it led to the immigration of various Syrians to neighbouring countries. In fact, about $60 \%$ of Syrians immigrated. This percentage hasn't been record during the last couple of decades. The greatest number of Syrian refugees went to the Hashemite Kingdom of Jordan. Based on statistical data issued by the United Nations High Commissioner for Refugees on November, 2018, there are 673,538 registered Syrian refugees in Jordan. It's estimated that there are about 100,100 unregistered Syrian refugees in Jordan.

It is known that being a refugee affects refugees' in psychological and economic areas. Refugees affects the countries that the refugees sought asylum at. In fact, they increase the demand on services, food, and security. Thus, the burdens of the governments of such countries shall increase due to the consequences of having refugees? All institutions must deliver services to refugees and provide them with attention. That applies to judicial institutions in general and Shariah courts in particular. That is because most of the refugees in Jordan are Muslims. That means that those Muslim refugees have to do paper works at Shariah courts in Jordan. It should be noted that some refugee families in Jordan are deprived from their civil rights. That is because those families were forced to immigrate without bringing the papers that prove their IDs and the personal status-related papers, such as: divorce and marriage documents. Under the Law of Procedure before Shariah Courts, Shariah courts have jurisdiction over the cases related to the personal status of Muslims ${ }^{8}$

Jordan went through a demographic change. In addition, due to the rapid technological developments, many

\footnotetext{
${ }^{1}$ Ibn Fares. Mu'jam Maqayees Al-Lugha, part 1, p. 97

${ }^{2}$ Ibn Manthoor, Mohammad bin Makram Al-Afreeqi. Lisan Al-Arab. $1^{\text {st }}$ Edition, Dar Sader, Beirut, part 12 , page. 16 Ibn Fares, Mu'jam Maqayees Al-Lugha, part 1, p.97

3 The international crisis: Meaning, running it and strategies for running it. Rachel Corrie Center for Human Right. http://www.rachelcenter.ps/news.php?action=view\&id=14272

${ }^{4}$ Taleb, Ahmad Hadi. The management of international crisis. Department of environmental management. Faculty of Economy and Management. Babel University, p.2

${ }^{5}$ The website of the United Nations High Commissioner for Refugees

https://www.unhcr.org/ar/4be7cc27207.html

${ }^{6}$ Yahya, Maha. Refugees and the industry of the Arab regional mess. Carnegie Middle East Centre and Carnegie Endowment for International Peace. Retrieved on 9/11/2015,https://carnegie-mec.org/2015/11/09/ar-pub-62393

${ }^{7}$ Jasem, Ahmad Lateef. The crisis of forced immigration and its social and psychological impacts. An article in Hadarah Journal. 8/2017, p.132

${ }^{8}$ Article (105) of the Jordanian Constitution states the following: (Only Shariah courts have jurisdiction over the following cases in accordance with the laws applicable at these courts: a)-The cases related to the personal status of Muslims).

Article 2/16 of the Jordanian Law of Procedure before Shariah Courts: (Shariah courts have jurisdiction over the following cases: the cases related to the personal status of Muslims)
} 
sectors in Jordan developed significantly. Jordan also went through consecutive crises. Thus, the impacts of such circumstances affected the implementation of the Law of Procedure before Shariah Courts in various aspects. Some of those aspects are identified below

*Notification:

In order to carrying out the litigation procedures in accordance with the Law of Procedure before Shariah Courts, the involved parties in the cases must be notified. Notifications are usually sent to the defendants. That is because defendants don't have knowledge about the case being filed to the court. As for the claimant, he is one who filed the case to the court. He was also informed about the hearing session. Thus, he is considered as a party who has been notified earlier. The valid notification is the basis for having valid litigation procedures. Changes were made to the Law of Procedure before Shariah Courts for acknowledging electronic notification as valid notification method. Under the latter law, judicial documents may be sent to the parties via electronic method ${ }^{1}$. However, they must be stamped by the court and signed by the judge. The Law of Procedure before Shariah Courts permits sending the judicial documents through any company that is approved by the Chief Justice ${ }^{2}$. Those changes were made to the Law of Procedure before Shariah Courts in order to keep up with the technological development.

Under the Law of Procedure before Shariah Courts, Publication is a valid method for notifying the defendant. That applies in case the defendant's place of residence isn't identified and the court is convinced that it's impossible to notify the defendant through the conventional methods. Article 23/1 of the Law of Procedure before Shariah Courts states the following: (If the court is convinced that there isn't method for notifying a party through the aforementioned procedures for any reason, it may decide to notify the party through one of the following methods:

a)- The court may hang on a copy of the judicial paper on a conspicuous place on the wall of the court. In this case, it shall hang on another copy of this paper on a conspicuous place on the wall of the last house that the party was residing in or on the wall of the last work place that the party was working in. That applies in case the court is familiar with the address of the last house he was residing in or the last workplace he was working at. B)-The court may publish a post in one of the local daily newspaper).

That means that Shariah court asks the claimant about the defendant's last place of residence. Then, it sends the statement of claim, court decision or any other judicial document to the defendant's last place of residence ${ }^{3}$. The notification record may be returned to the court with having the court officer confirming in writing that defendant's place of residence is unknown after investigating it. In this case, the court shall be convinced that the defendant's place of residence is unknown. It shall be convinced that the defendant can't be notified through the conventional methods ${ }^{4}$. The defendant's last place of residence may be located outside Jordan with being identified in details. In this case, the official authorities must send the notification to the defendant to this place. Based on the result of sending this notification, the court may decide to notify the defendant through publication. This notification mechanism is determined by jurists under discretion ${ }^{5}$.

The latter case applies to normal conditions. However, it's difficult to apply that when having many Iraqi and Syrian refugees filing many lawsuits against defendants whose place of residence may be unknown or located in Syria or Iraq. In this case, it is very difficult for the official authorities to send the notifications to such defendants. That is because these countries suffer from conflicts and wars. In addition, it is difficult for courts in Jordan to address the concerned courts in Syria or Iraq and ask them to send notifications. That is because the latter courts may have suspended their hearing sessions due to conflicts and destructions. For instance, Shariah courts in some Syrian cities suspended their hearing sessions due to the lack of resources and poor work conditions ${ }^{6}$. Many courts in Iraq suspended their hearing sessions due to the destruction and loss of their records. The same applies to other public institutions in Iraq ${ }^{7}$.

In the light of such conditions, the trial judges notify the defendants whose last place of residence is located in Syria or Iraq through publishing a post in a daily newspaper. The defendant's last of place of residence is identified in this case through after asking the claimant about the defendant's last place of residence and getting information from the Department of Residence and Borders that is affiliated with the Public Security Directorate. The latter department must confirm that the defendant didn't enter the country. In this case, the defendant's place of residence shall be considered unknown. In this case, the public authorities shall send a notification to the defendant's last place of residence in Iraq or Syria. That serves as a violation for the notification mechanism is determined by jurists under discretion. However, it was necessary to make such a violation due to the conditions

${ }^{1}$ That is stated through article 18/ paragraph 3 of the Law of Procedure before Shariah Courts

${ }^{2}$ That is stated through article 30/ paragraph B of the Law of Procedure before Shariah Courts

${ }^{3}$ Al-Khoori, Fares. Civil procedures. $2^{\text {nd }}$ edition. Al-Dar Al-Arabeye. Amman, 1987 AD, p.283

${ }^{4}$ A decision issued by Shariah Amman Court of Appeal on 16/8/1966. It holds No. 14692

5 A decision issued by Shariah Amman Court of Appeal. It holds No. 34101

A decision issued by Shariah Amman Court of Appeal. It holds No.37684

${ }^{6}$ That is cited from Smartnews Agency,https://smartnews-agency.com/ar/wires/

7 An article about the state of Iraq during the post-war period: Judiciary in Iraq. Aljazeera. Retrieved on 1/10/2005, https://www.aljazeera.net/programs/iraqafterthewar 
experienced Jordan. However, in case the defendant is inside Jordan or in countries other than Syria and Iraq, the usual notification mechanism shall be implemented.

Since the beginning of the Iraqi and Syrian crises, obstacles have been faced in implementing the litigation procedures. Since the beginning of such crises, obstacles have been faced in implementing article 23 of theLaw of Procedure before Shariah Courts. The latter article is related to notifying parties. Due to facing such obstacles, it was decided to refrain from sending a notification to the defendant whose last place of residence is located in Syria or Iraq. It was decided to consider this defendant' place of residence as being unknown in this case. However, the defendant's place of residence may be unknown for the claimant. In this case, the trial judge shall ask the claimant to submit an evidence proving that he doesn't know the defendant's place of residence. This evidence is determined in accordance with the judge's discretionary power. This evidence may be represented in taking the oath by the claimant or submitting a personal evidence.

*Delegation in taking the oath and listening to the testimony of the witness:

Under article 72 of the Law of Procedure before Shariah Courts, the court may delegate a judge in another country to let the concerned party take the oath in front of him/her. However, in the light of the contemporary conditions, it is difficult for Shariah courts in Jordan to delegate a judge in Syria or Iraq to let the concerned party take the oath in front of him/her. That is because it's difficult for Shariah courts to communicate with the courts in Syria and Iraq. It's difficult to ask the concerned part to come to Jordan due to the difficulty of leaving such countries. In the light of such conditions, Shariah courts in Jordan shall ask the concerned court that has jurisdiction in Syria or Iraq to notify the concerned party and ask him/her to take the oath. In case a Shariah court in Jordan became fully convinced that the concerned party shall not take the oath, the court shall ask the other party to take the oath to prove his/her claim. The same applies to delegating a judge in another country to let the concerned party make a testimony.

Recent changes to the Law of Procedure before Shariah Courts include delegating the notary public in one of the Jordanian embassies or consulates. This delegation shall authorize the notary public to let a specific party take the oath. It can be given to the notary public in the countries that don't have a judge that can be delegated (e.g. European and non-Islamic countries) ${ }^{1}$.

Recent changes to the Law of Procedure before Shariah Courts include taking the change to the demographic structure and the increase of the population in Jordan into consideration. Thus, if the adversary doesn't have a known place of residence in Jordan nor outside Jordan, the court that has jurisdiction in this case is Amman Shariah Court $^{2}$

Section two: The impacts of international crises on making decisions under discretion by the Jordanian Shariah courts

International crises affected the implementation of the Law of Procedure before Shariah Courts. They affected the way decisions are made by Jordanian Shariah courts under discretion. That is because several changes are derived from international crises. For instance, international crises led to the change of the demographic structure and increasing the population size. That led to the increase of the demand on judicial services. Thus, several measures were taken to regulate the process of taking litigation procedures in the light of the increase of such demand.

Changes to the Law of Procedure before Shariah Courts include: enforcing a condition on filing appeals. To illustrate more, any appeal today must be filed by the attorney. However, in the past, the appeal can be filed by the appellant himself. Under article 140 of the latter law, the appeal must be filed to the court of appeal that has the spatial jurisdiction. That is also stipulated through the decisions issued by Shariah Court of Appeal under discretion $^{3}$. Therefore, if the appeal is filed by the appellant himself or filed to the court of first instance, the appeal shall be rejected and hearing sessions shall not be held to look into it. That is attributed to the failure in complying with the required procedures. Such procedures were set to regulate the process of filing appeals against the decisions issued by the court of first instance. It should be noted that filing an appeal to the court of first instance is a reason for rejecting the appeal due to the non-compliance with procedures. That is stipulated through amended article 140 of the Law of Procedure before Shariah Courts. The latter article was amended based on the decisions made by the judiciary under discretion. It was amended because it became inconsistent with the reality. It was amended because it doesn't take into consideration the recent changes that have occurred. Such changes include having a great number of lawsuits in courts. It was amended because it doesn't take into consideration its negative impact. For instance, under non-amended article, the appellant whose appeal is filed to the court of first instance and rejected shall not have adequate time to file an appeal against the judgment. In this case, he/she shall be deprived from his right to appeal which is granted to him by the law.

${ }^{1}$ That is stipulated through article 72/ paragraph 4 of the Law of Procedure before Shariah Courts

${ }^{2}$ That is stipulated through article 3/ paragraph 2 of the Law of Procedure before Shariah Courts. The latter paragraph states: (If the claimant and defendant don't have a known place of residence in Jordan, Amman Court shall have jurisdiction over the case)

${ }^{3}$ Look at the decisions issued by Shariah Amman Court of Appeal on 29/6/1996 (No. 13777, No. 21826, No. 24339, No. 27929, and No. 2940817) 
The divorce bill on appeal, and up to the appeal, the case file against which the judgment was appealed to the Court of Appeal, and until its appeal to appeal from the consideration of the appeal by appeal after the court of first instance procedures; And according to the Code of Sharia Procedures, by appealing with an appeal again by appealing, the Code of Sharia Procedures, the Code of Sharia Procedures, and it is obligatory to respond. Formed by the Court of Appeal.

Among the topics affected by the jurisprudence is the issue of eligibility. It is science that the age of eligibility is followed in private international law to the nationality law as a general rule. ${ }^{1}$ Accordingly, the Jordanian Code of Sharia Procedures deals with full eligibility according to that and the consequences thereof with regard to the marriage contract according to the Jordanian Personal Status $\mathrm{Law}^{2}$, as the form of the marriage contract in Jordan is not imagined that it will be outside the scope of the court under penalty of liability, and this is in contrast to what has been done. In Syria, where the marriage takes place in a common manner and was confirmed after a period of time in the Sharia courts, and there is no penalty for that and no breach of their administrative system; Hence, the Sharia courts found themselves in front of a reality that must be addressed, which is that the prevailing custom in some neighboring countries - such as Syria - marries girls to those below the legal age and the minimum age has not been fulfilled, ${ }^{3}$ which is the age of fifteen. Those of this age, especially since it is most likely of those who have given birth, and their interest in establishing the lineage in addition to the interest in establishing marriage is imperative. With this, the amendment came in the Code of Sharia Procedure, which restored the eligibility of persons in the law of the country to which they belong to their nationality as it is in the general rule, and referred the objective conditions for the validity of marriage to the law of each of the spouses in response to the change of jurisprudence. $^{4}$

It is worth noting that what has been established in the Jordanian Sharia courts in accordance with the Jordanian Sharia Procedure Code by establishing this case, and in the mechanism for hearing personal evidence specifically on cases of proof of marriage or lineage, in support of Article 67 of the Code of Sharia Procedures, which specified that the testimony of witnesses The case is proven that constitutes conviction with the court, and pursuant to what the judicial jurisprudence has established that the personal evidence proves the details of the claim - in general - or that the testimony is original and not secondary, that is, it is not based on lucidity. Fame on the prosecution to prove marriage and lineage in cases of refugees who have lost documents that prove their civil and personal status, according to Article 1688 of the Code of Judicial Rulings, while other plaintiffs are imposed on what is not imposed on them as paying the fines stipulated in Article 36 of the Personal Status Law Indeed, by presenting asylum cards issued by the United Nations High Commissioner for Refugees, or the identification service card issued by the local authorities in Jordan, it is sufficient to identify them. Without requesting the presentation of documents from the Civil Status and Passports Department.

The second topic: the impact of international crises and the Universal Declaration of Human Rights on the rights of missing persons and refugees.

The First Requirement: the Impact of International Crises on Provisions Affecting the Rights of Missing Absentees

The absent absentee: he is the absent one whose life is unknown from his death ${ }^{5}$ and has no knowledge of his whereabouts.

The Jordanian Personal Status Law No. 36 of 2010 and amended pursuant to Law No. 15 of 2019 incorporated the provisions of the absent and the missing in support of the provisions of Articles (143) and (246-253) thereof, which include a distinction between a wife and her husband who was missing due to loss, and a ruling for the death of the missing, and in these two cases It obliged the judge to search and investigate him before ruling on annulment or loss by means that the judge deems sufficient, and what work has been established in the courts must address the departments that may be concerned with this, such as the security authorities, and the Kingdom's embassy in the country in which the person was lost if he lost outside the Kingdom in addition to more From a local newspaper; ${ }^{6}$ Accordingly, the court must conduct the investigation of the missing absentee according to the

\footnotetext{
${ }^{1}$ This is according to the text of Article 12 of the Jordanian Civil Law, which states: "The law of the country to which they belong to their nationality applies to the civil status and capacity of persons ..." The Syrian civil law came in the same sense in Article 12/1, as well as the Iraqi Civil Law in Article 18.

Al-Masry, Muhammad Walid, Al-Wajeez fi Sharh of Private International Law, 4th Edition, Dar Al-Thaqafa, Amman, 2019 AD, p. 121, Antaki, Rizk Allah, Fundamentals of trials in civil and commercial matters, 5th Edition, Damascus University Press, 1962 , p. 46.

${ }^{2}$ And that is in Article (10) of the Personal Status Law in which the stipulation for the age of marriage is that both suitors must complete eighteen suns, and that a person who has completed fifteen years may, according to special circumstances, marry .

And it came in the light of Paragraph B of Article 43 of the Sharia Procedure Code.

${ }^{3}$ Khaled, Hisham, Law applicable to the form of marriage (a comparative study), 1st Edition, Ma'arif Institute, Alexandria, 2006 AD, p.75.

${ }^{4}$ And that is in Articles (186 and 187) of the Code of Sharia Procedure.

${ }^{5}$ Abd al-Ghaffar, Jamal Abd al-Wahhab, Provisions of the Missing in Islamic Law, 1st Edition, New University House, Alexandria, 2003 AD, p. 17, Al-Shdeifat, Ibrahim Rashid, Provisions for the Missing in Islamic Jurisprudence and Jordanian Laws, Edition 1, Ministry of Awqaf Press, Amman, 2004, p. 14

${ }^{6}$ Al-Shdeifat, Ahkam Al-Misad in Islamic Fiqh and Jordanian Laws, p137
} 
available methods specified by the Code of Sharia Proceedings, in Article 23, since the investigation is one of the judicial papers that Article 23 of the Code of Sharia Procedures intended to inform.

What happened to work in the Sharia courts if the missing person is inside the Kingdom, the judge of the matter investigates in writing the Sharia courts in the Kingdom in addition to the media. But if he is outside the country, it is written to the competent authorities in that country in which he was lost, such as the Kingdom's embassy in that country, but after the occurrence of the Iraqi and Syrian crisis, the methods of investigation by the usual means became impossible and impossible. Through it before, and like that the International Committee of the Red Cross, which - in most cases - expresses reservations - to investigation requests and does not give a clear result, and the United Nations High Commissioner for Refugees, as well as the Residency and Borders Department of the Jordanian Public Security Directorate, to ascertain the status of his entry The Kingdom or not, as it is not feasible to address official bodies or institutions within the countries in which chaos, wars, and sectarian conflicts that often affect cases of enforced disappearance, arrest or kidnapping, and in such a case it is not possible to convert to a specific destination To give a result of the investigation of the missing person in those countries; Such as hospitals in it or the embassies and consulates of the Kingdom that are no longer operating in those countries; Therefore, the investigative method has become satisfied with the media, such as the press, and annotations issued by the Residency and Borders Department without sending judicial papers that include the investigation to the lost area, according to what the judge sees ${ }^{1}$.

\section{The second requirement: the Universal Declaration of Human Rights}

The United Nations Charter was the first international document of a universal or near-universal character that included the text of the principle of human rights, ${ }^{2}$ However, what was stated in the charter was not enough to be convinced to show the extent of the United Nations Organization's interest in the issue of human rights, ${ }^{3}$ so it was the main starting point for drafting the Universal Declaration of Human Rights. Whereas the Universal Declaration of Human Rights included an affirmation of the recognition of the inherent dignity of all members of the human family, and of their equal and inalienable rights as the basis for freedom, justice and equality; The introduction also clarifies the link between respect for human rights, the rule of law and freedom in the internal order on the one hand, and world peace on the other hand ${ }^{4}$.

The Charter of the United Nations specifically calls on the organization to provide assistance in settling international disputes by peaceful means, including arbitration and judicial settlement, and in the same sense came international humanitarian law, ${ }^{5}$ and to encourage the progressive development of international law and its codification. ${ }^{6}$

In compliance with what was stated in the charter on assistance in settling international disputes by peaceful means, which is considered one of the new developments in the law of Sharia procedures, the last amendment stipulated the establishment of reform, mediation and family reconciliation offices in Sharia courts, whose goal is to resolve family disputes through mediation or conciliation Thus ${ }^{7}$, the Jordanian legislature is in line with some legislations in the Arab countries in this regard, such as the Egyptian legislation. ${ }^{8}$ Especially since personal status is a fertile field for the application of mediation and family reform, which play an important role in draining the sources of domestic violence.

Finally, the amendment to the Code of Sharia Procedures in 2016 included many of the amendments that arise from the necessities of reality and its developments to it, and such as what was stipulated in the old law in the event that the opponent's payment is proven to lack the spatial jurisdiction of the court examining the case, the result of the case's dismissal This is what the jurisprudence has established and worked on; ${ }^{9}$ However, due to a lot of hardship on the litigants, the amendment came in Paragraph (b) of Article (9) of the Sharia Procedures Law enforceable by referral, which stipulates: "If the court decides that it is not spatially competent, it must refer the case to the competent court, which must Accept it "and that is an abbreviation of litigation procedures, in order to

\footnotetext{
${ }^{1}$ Amman Sharia Court of Appeal Decision No. 77162/2010/2214 dated 8/18/2010.

Al-Amrousi, Anwar, The Principles of Sharia Pleadings in Personal Status Matters, 1st Edition, Dar Al-Fikr University, Alexandria, 2005 AD, p. 436.

${ }^{2}$ Al-Dabbas, Ali Muhammad and Ali Abu Zaid, Human Rights and Freedoms, 1st Edition, House of Culture, Amman, 2017 AD, pg.53.

${ }^{3}$ The Universal Declaration of Human Rights: It is an international rights document that represents the declaration adopted by the United Nations on 10/12/1948 in Chaillot Palace in Paris, Majzoub, Muhammad Saeed, International Human Rights Law, First Edition, Modern Book Foundation, Beirut, 2016, p. 90, Al-Dabbas, Human Rights and Freedoms, p. 60

${ }^{4}$ Al-Dabbas, Human Rights and Freedoms, p. 61, Al-Fatlawi, Suhail Hussein, International Humanitarian Law, 6th Edition, House of Culture, Amman, 2007 AD, p.20.

${ }^{5}$ And that in Article 33 of the Charter.

${ }^{6}$ And that in Article 13 of the Charter.

${ }^{7}$ This is in support of the provisions of Paragraph (c) of Article (11) of the Code of Sharia Proceedings. Where the Egyptian Family Courts Establishment Law No. 10 of 2004 was issued, issued in the Official Gazette No. 12 years 47 issued on 3/4/2004.

${ }^{8}$ See the decision of the Sharia Amman Court of Appeal No. 40491 dated May 7, 1996

${ }^{9}$ This is in support of the provisions of Articles (158-170) of the Code of Sharia Procedures
} 
save the plaintiff by not incurring a new lawsuit fee again because of its dismissal, ${ }^{1}$ as stated by the previous law.

As stipulated in the amendment contained in the law, the possibility of appeal to the Supreme Sharia Court, which granted the right to those who were found to have not fulfilled their right before the courts of the first instance (courts of first instance) and courts of second degree (courts of appeal) to appeal the decisions issued by the courts of appeal to the Sharia Supreme Court; But with controls and conditions stipulated by law.

As well as the establishment of the Sharia Public Prosecution and its powers; ${ }^{2}$ It should be noted that this amendment was in line with the purpose for which the judiciary was set up, which is to establish justice and preserve the interests of the litigants, and take into account the public interest of legislation, which is to bring interests and ward off corruption from those charged, especially since this is stipulated in the laws of some Arab countries. ${ }^{3}$

\section{Conclusion}

After researching the impact of international crises on the personal status of refugees (the Jordanian Code of Sharia Procedures No. 31 and its amendments as a model), and studying it, we concluded the following results:

1.Many internal and external influences cast a shadow over the Sharia Procedure Code in terms of application in Sharia courts.

2.The ability of the Sharia Procedure Code to keep pace with many changes has emerged, especially the problem of humanitarian asylum.

3.The urgent need for judicial jurisprudence has emerged to break the deadlock of some provisions of the Code of Sharia Procedures, in order to cope with internal and external influences.

Based on the foregoing, the following can be recommended:

1.Continuous follow-up of jurisprudence, with the possibility of revoking it in case it is proven ineffective, and turning to the corrections; Through unified judicial references that have sufficient immunity for that.

2. Criticism of judicial norms and international agreements that do not comply with Islamic law and do not meet the needs of refugees and forcibly displaced persons, and preserve the legal heritage that is approved by the Shariah, and explain the necessity of invoking the law of God by the judges, with legal follow-up sponsored by the competent authorities.

3. Promote the contemporary jurisprudence to accommodate its developments, as the Sharia judiciary is an area for the application of Islamic law.

\section{References}

1.Antaki, Rizk Allah, The Principles of Trials in Civil and Commercial Subjects, 5th Edition, Damascus University Press, 1962 AD.

2.Ibn Faris, Abu al-Husayn Ahmad bin Zakaria, Dictionary of Language Standards, edited by Abd al-Salam Muhammad Harun, Dar al-Fikr, Damascus, 1979 AD.

3.Ibn Manzur, Muhammad Ibn Makram Al-Afriqi, Lisan Al-Arab, 1st Edition, Dar Sader, Beirut.

4.Jasim, Ahmed Latif, The Displacement Crisis and its Psychological and Social Effects, Article in Hadara Magazine, Issue Twenty, 8/2017.

5.Khaled, Hisham, Law applicable to the form of marriage (a comparative study), 1st Edition, Ma'arif Institute, Alexandria.

6. Al-Khoury, Faris, The Fundamentals of Human Rights Trials, 2nd Edition, Al-Dar Al-Arabiya, Amman, 1987 AD.

7.Al-Dabbas, Ali Muhammad and Ali Abu Zaid, Human Rights and Freedoms, 1st Edition, House of Culture, Amman, 2017 AD.

8. Daoud, Ahmad Muhammad, Appeal Decisions on the Principles of Sharia Trials and Procedures of the Case, Revised Edition, House of Culture, Amman, 2004 AD.

9.Al-Shdeifat, Ibrahim Rashid, Provisions for the Missing in Islamic Jurisprudence and Jordanian Laws, Edition 1, Ministry of Endowments Press, Amman, 2004 AD.

10. Student, Ahmed Hadi, International Crisis Management, Environmental Management Department, College of Management and Economics, University of Babylon.

11. Abdel Ghaffar, Gamal Abdel Wahab, Provisions of the Missing in Islamic Law, 1st Edition, New University House, Alexandria, 2003 AD.

12. Al-Amrousi, Anwar, The Principles of Sharia Pleadings in Personal Status Matters, 1st Edition, Dar Al-Fikr Al-Jami', Alexandria, 2005 AD

13. Al-Majzoub, Muhammad Saeed, International Human Rights Law, 1st Edition, Modern Book Foundation,

${ }^{1}$ This is in support of the provisions of Articles (171-183) of the Code of Sharia Procedures

${ }^{2}$ Such as the Egyptian Code of Civil and Commercial Procedure No. 13 of 1986, where Article (108) of it stipulates: “- the defense of lack of local jurisdiction and the payment to refer the case to another court for the same dispute before it ..."

${ }^{3}$ Al-Amrousi, The Principles of Sharia Pleadings in Personal Status Matters, p. 692. 
Beirut, 2016.

14. The Rachel Corrie Center for Human Rights The International Crisis: its concept - management and tools.

15. Al-Masry, Muhammad Walid, Al-Wajeez in Explaining Private International Law, 4th Edition, House of Culture, Amman, 2019.

16. Yahya, Maha, Refugees and the Industry of Arab Regional Chaos, Carnegie Middle East Center, Carnegie Endowment for International Peace, 11/9/2015 ,https://carnegie-mec.org/2015/11/09/ar-pub-62393

17.An article on post-war Iraq, the judiciary in Iraq, Al-Jazeera Media Network, 10/1/2005 https://www.aljazeera.net/programs/iraqafterthewar

18.The website of the United Nations High Commissioner for Refugees . https://www.unhcr.org/en/4be7cc27207.html

19. The Arab League's website .http://www.lasportal.org/sites/search/Pages/result

20. Smart News Agency https://smartnews-agency.com/ar/wires/ 